\title{
Biodiversity of Freshwater Shrimp of the Genus Macrobrachium (Decapoda Palaemonidae) in the Nyong Basin of Cameroon
}

\author{
Gertrude Estelle Yogback $^{1,2^{*}}$, Gideon Aghaindum Ajeagah ${ }^{1}$, Lordon- \\ Champlain Djieto ${ }^{3}$, Silas Lagat Cheruiyo4 ${ }^{3}$, Dickson Achuo Enah ${ }^{1}$, Mama \\ Mbouoombouo $^{1}$, Chrispin Kowenje ${ }^{5}$
}

\author{
${ }^{1}$ Laboratory of Hydrobiology and Environment, Faculty of Sciences, University of Yaoundé I, BP 812 Yaoundé. \\ ${ }^{2}$ Ministry of scientific research and innovation, laboratory of natural disaster, National Institute of Cartography, BP 157- \\ Yaoundé. \\ ${ }^{3}$ Laboratory of Zoology, Faculty of Sciences, University of Yaoundé I, B.P. 812, YAOUNDÉ, CAMERooN. Courriel. \\ ${ }^{4}$ Department of Physical Sciences, Jaramogi Oginga Odinga University of Science and Technology. P.O.Box 210 - 40601 \\ Bondo - Kenya. \\ ${ }^{5}$ Department of Chemistry, Maseno University, P.O. Box 333, 40105 Maseno, Kenya \\ Corresponding autheur: yogbackgertrude@yahoo.com
}

\begin{abstract}
The population of shrimps, especially the macrobrachium genus, has been affected with habitat pollution and overexploitation. Shrimps provide a major protein source to animals higher in the food chain. The importance of studying the ecology of shrimps in their different habitats helps in their preservation and provides possibilities of carcinoculture. This study examines diversity, ecology and reproduction parameters of fresh water shrimps of the genus macrobrachium in the basins of Lepmassoun and Ondoamedza rivers. Lepmassoun and Ondoamedza rivers form part of the larger Nyong river basin in Cameroon. In situ water physicochemical parameters were determined on site, preserved water samples used in mineral analysis and subsequent ecological health assessment. Shrimps were sampled using the scoop method with hand nets and analyzed. Sampling was done in 5 seasons distributed from January 2017 to February 2018. The results of physicochemical parameters indicate that water in the two rivers was slightly mineralized, sufficiently oxygenated and slightly turbid. It was generally a non-polluted ecological zone for shrimps. A total of 113 shrimps distributed among 14 species were collected. The shrimp population included Macrobrachium macrobrachion Macrobrachium idae, Macrobrachium rude, Macrobrachium niloticus , Macrobrachium dux Macrobrachium spl, Macrobrachium $\quad s p 2, \quad$ Macrobrachium sp3,Macrobrachium sp4, Macrobrachium sp4, Macrobrachium sp5, Macrobrachium sp6, Macrobrachium sp7, Macrobrachium sp8 and Macrobrachium sp9.In the river Odoameza 11 species
\end{abstract}

were collected among which Macrobrachium sp8 (26.02\%) is abundant, though, in the river Lepmassoun we collected 10 species dominanced by Macrobrachium macrobrachion (22,5\%). The species Macrobrachium macrobrachion is most ubiquiste throughout river Lepmassoun $(\% O=83.33 \%)$ The river basin of Lepmassoun had a higher population of Macrobrachium macrobrachion with a percentage occurrence of $66.67 \%$. then It is concluded that the water in the two river basins is of good ecological quality for shrimp survival with species Macrobrachium macrobrachion dominating in the river lepmassoun. In the river Ondoameza Macrobrachium sp8, Macrobrachium idea, Macrobrachium macrobrachion,Macrobrachium sp4 having all the percentage of occurrence $(\% O)$ of $66.67 \%$ are relatively represented. Only Macrobrachium dux have Ovigerous females in our study. This Ovigerous females ranged from 50.38 to $64.18 \mathrm{~mm}$ and egg size varied from 1.7 to $2 \mathrm{~mm}$. The prawn attained a maximum total length and weight of $64,18 \mathrm{~m}$ and 2,96 $\mathrm{g}$ respectively. In our basins slope the Macrobrachium dux reproduces twice year during the big dry season and small dry season since production is early and the eggs are rather broad by consequence the larval development is shortened.

Keywords - Shrimp; Macrobrachium; ovigerous, Lepmassoun; Ondoamedza. 


\section{INTRODUCTION}

The world production of shrimp exceeded $240 \mathrm{~T}$ in the year 2000 , which roughly corresponds to $20 \%$ of the total quantity produced (Sampaio, Silva et al. 2007).Africa's contribution to shrimp production remains very minimal with almost null participation in carcinoculture (FAO 2010). The main species of fresh water shrimp with commercial value belongs to the family paleamonidae (Nnana Noah, 2010). Within this commercially viable family, the genus Paleamon, Leander, and Macrobrachium are dominant (Monod 1966). Furthermore, Macrobrachium (Bate, 1868) has been found in most of the biogeographic areas and more than 240 species have been recorded (De Grave and Fransen 2011).

Overfishing and pollution affects biodiversity of aquatic animals (Omwoma 2012). Continuous aquatic system assessment for water quality and biodiversity helps in system management and product quality. Use of agricultural products such as pesticides and fertilizers including urbanization are known to affect water quality and species diversity (Allan and Flecker 1993). The fact that production of shrimp in Africa has remained low leads scientists to determine possible reasons and mitigation measures over the same. This is particularly the case given that Africa is dominated with several fresh water bodies that are conducive for shrimp production.
Furthermore, shrimps are of great ecological, medical and socio-economic interest. They can be characterized by their life cycle (New and Singholka 1985) and they play a significant role in water trophic networks. They are regarded as indicators of good water quality. In addition, the market of shrimps in the east is a gold basket and their price is higher than fish. Such good qualities of shrimps makes them an important subject of study especially their ability to provide high protein content in different diets (Doume doume, Toguyen et al. 2013).

In Cameroon, shrimps of the genus Macrobranchium (Herklots 1851) might be exploited by artisanal fishermen that use bow nets. There is little data available on the ecology and the biology (reproduction) of shrimps in Cameroon (Doume doume, Toguyen et al. 2013), (Tchakonte, Ajeagah et al. 2014)and (Ajeagah, Yogback et al. 2017), (Ajeagah, Yogback et al. 2018). As such we endeavor herein to characterize the ecology of shrimps river Lepmassoun and the river Ondomedza. Lepmassoun and Ondoamedza rivers form part of the larger Nyong river basin in Cameroon. The study considers biodiversity of shrimps and ecological quality parameters of the two river basins.

\section{MATERIAL AND METHODS}

\subsection{Study site}

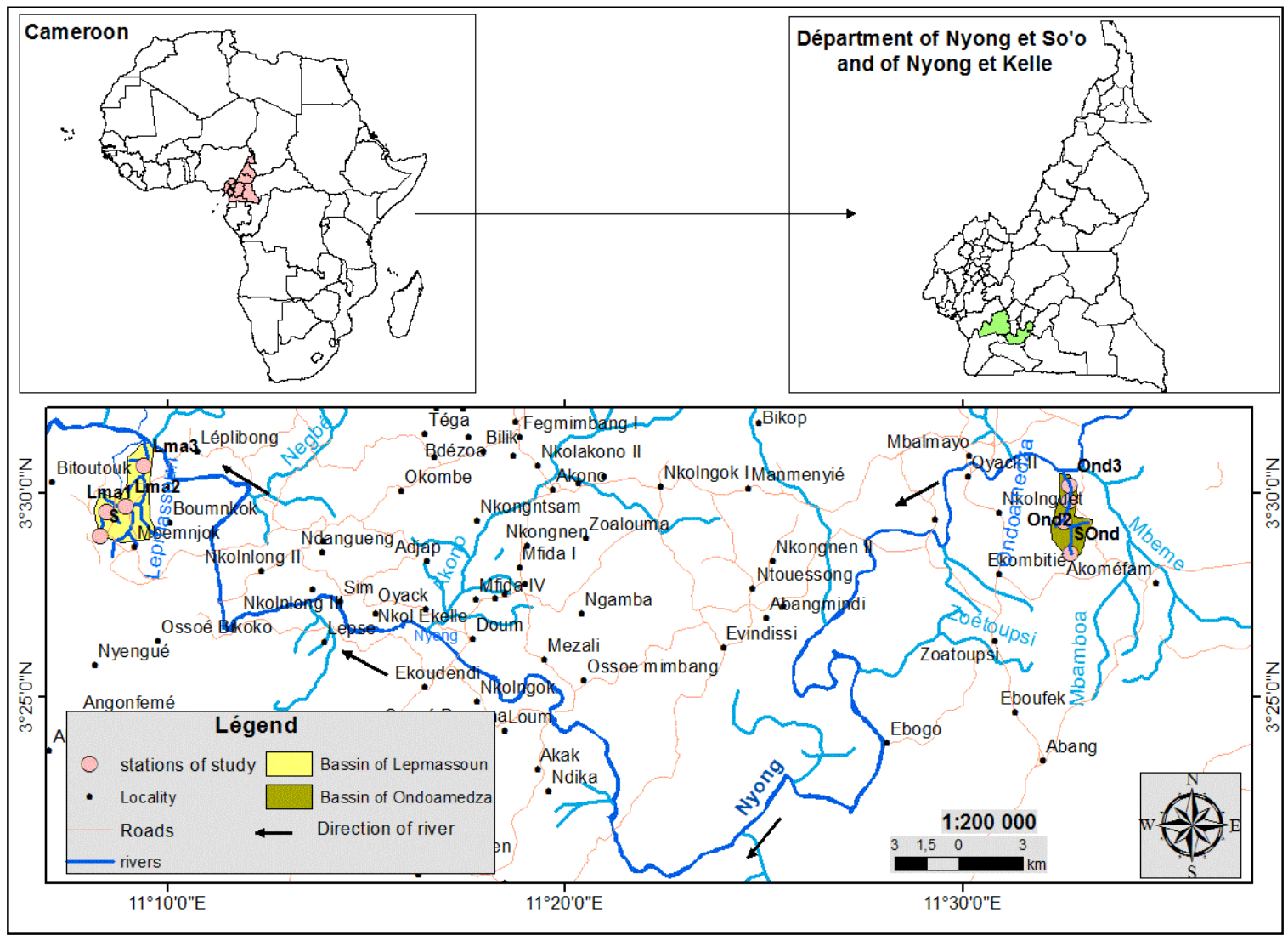

Fig.1: Study areas that comprise of River Lepmassoun and River Ondoamedza along River Nyong in Cameroon. Lma 1 -3 are sampling points on Lepmassoun River while Ond 1-3 are sampling points along the Ondoamedza River. 
The study site, Nyong River Basin, comprises of two tributary rivers namely Lepmasoun and Ondoamedza (Fig. 1). These two river tributaries lie within an equatorial climate. Such a climate is characterized with four main seasons per year (two dry seasons and two wet seasons). The main dry season is experienced from December to February while the main wet season is experienced from September to November. The rainfall distribution ranges from $3000 \mathrm{~mm}$ per month to $1500 \mathrm{~mm}$ per month in the two basins resulting to the entire area being covered with forest (Olivry 1986). Six stations were identified as marked in Fig. 1 for sampling and they were identified as Lma1 (0329' 41,164" N; 118' 45,068" E), Lma2 0329' 44 ";118' 45,072" E and Lma3 (0330' 58,19" N;119' 29,727" E) for the river Lepmassoun;Ond1 (0329' 40,25 " N;1132' 38,336" E), Ond2 (0330' 1,451" N;1132' 43,048" E) and Ond3 (0330' 18,166' ' N;1132' 37,413" E) for the river Ondoamedza (see Fig. 1).

\subsection{Physicochemical parameters determination}

Physicochemical parameters including Temperature, Dissolved Oxygen, pH, Electric Conductivity and TDS were determined insitu. Dissolved $\mathrm{CO}_{2}$, Alkalinity $\left(\mathrm{HCO}_{3}{ }^{-}\right)$, Nitrates $\left(\mathrm{NO}_{3}^{-}\right)$, Nitrites $\left(\mathrm{NO}_{2}^{-}\right)$, Orthophosphate $\left(\mathrm{PO}_{4}{ }^{3-}\right)$, and Ammoniacal Nitrogen $\left(\mathrm{NH}_{3}-\mathrm{N}\right)$ were determined using standard procedures on unfiltered water samples. Shrimps were collected using a scoop method with a hand net and preserved with formalin in containers that had been washed with alcohol (95\%). In the laboratory, the shrimps were identified by placing them in a petri dish, sorted accorded to their morphology and identified using a binocular magnifying glass according to cited keys of identification features (Monod 1966), (Powell 1980); Won and Lawrence, 1988; Bruce and Thomas, 1991; (Day, Stewart et al. 2001)).

\subsection{Determination of Shrimp biodiversity}

The diversity index of (Shannon and Weaver 1948) was used in determination of species distribution within their habitat (Equation 1).

$$
N=\frac{n}{N} x 100
$$

Where $n=$ numerical proportion of a taxonomic group, $N=$ total number of individuals

Percentage species of occurrence $(\% \mathrm{SO})$, the percentage of stations where a species is sampled was determined using Equation 2 (N'zi, B.G. et al. 2008).

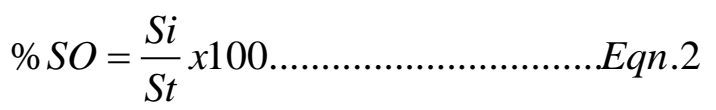

Where: $S i=$ number of stations where species $i$ was captured, $S t=$ total number of stations prospected.

\subsection{Reproduction of shrimp}

Ovigerous females were identified and sex-ratio determined according to equation 3 (Agadjihouede 2006). The number of eggs in the female was physically counted.

$$
\begin{aligned}
& S R=\frac{N m}{N f} \ldots \ldots \ldots \ldots \ldots \ldots \ldots \ldots \ldots \ldots . . . . . . . . . . . . . . . . . . . n .3 \\
& \text { Where } N f=\text { number of females and } \mathrm{Nm}=
\end{aligned}
$$
number of males

The femininity rate was determined using equation 4

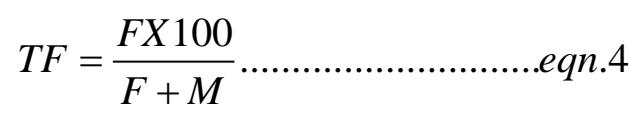

Where $F=$ number of females in the given sample and $M=$ number of males in the given sample. Fecundity was done by counting the number of eggs from the weight sampling method. The eggs were taken out of the pill organizers and wrung out on blotting paper. A fraction of $0.05 \mathrm{~g}$ was then taken and counted under a magnifying glass. From the results, absolute fertility (Equation 5) and relative fertility (Equation 6) was determined where absolute fertility is the total number of eggs and relative fertility is the number of eggs per unit of body weight.

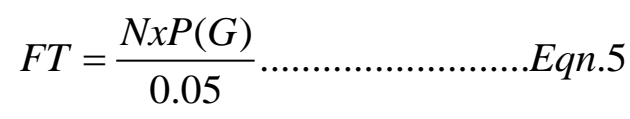

Where FT = absolute fertility, $N=$ number of eggs in the $0.05 \mathrm{~g}$ fraction, $P(G)=$ gonad weight .

$$
F R=\frac{F T x 1}{P t} \ldots \ldots \ldots \ldots \ldots \ldots \ldots \ldots \ldots \ldots \ldots \ldots \ldots
$$

Where FR = relative fertility; $F T=$ absolute fertility; $P t$ $=$ body weight

The reproductive period was determined through the gonado-somatic relationship (RGS) given by equation 7 (Goore Bi 1998). This relationship reflects the progress of maturity of the ovaries. The higher this ratio, the closer is the laying, when it is weak, the female is in a state of sexual rest. In the state of immaturity, the value of this relation is zero or near zero.

$$
R G S=\frac{P(G)}{P t} x 100 .
$$

Where RGS = Gonado-somatic relationship; $\mathrm{P}(\mathrm{G})=$ Gonad weight; $P t=$ body weight

\section{RESULTS}

\subsection{Physicochemical parameters}

The data for physicochemical parameters of River Lepmassoun and River Ondoamedza are recorded in Table 1. During the period of study, abiotic parameters did not significantly vary according to the test of Kruskal Wallis. However, temporarily, some parameters varied 
except for temperature, dissolved oxygen, oxygen content, MES, color, oxydability, ammoniacal nitrogen and magnesium hardness.

Temperature was constant with an average of $21.66 \pm 0.86^{\circ} \mathrm{C}$ in River Ondomedza. However in River Lepmassoun, it varied from one season to another according to Kruskal-wallis test $(\mathrm{P}<0,05)$ of $19,5{ }^{\circ} \mathrm{C}$ (GSP) at $23{ }^{\circ} \mathrm{C}$ (PSP). In the river Lepmassoun, the profile of variation of turbidity lies between 0 (GSPLma1) and 48 FTU (GSS 2018-Lma3) and significantly varied from one season to another. That of MES was 0 $\mathrm{mg} / \mathrm{l}$ (GSS-Lma3 and GSP-Lma2) and $32 \mathrm{mg} / \mathrm{L}$ (GSS 2018- Lma 3) and did not vary significantly with an average of $8.2 \pm 8.47 \mathrm{mg} / \mathrm{L}$, according to the test $U$ of Mann Withney. In River Ondoamedza, the minimal values of turbidity, MES and colors are of $0 \mathrm{FTU}, 0 \mathrm{mg} / \mathrm{L}$ and $52 \mathrm{Pt}$-Co respectively and the maximum values are of 20 FTU (Ond1- GSS), 15 mg/L (Ond3- PSS) and 362 (Ond3- PSS) Pt-Co. With regard to the color, it did not vary significantly in the rivers under study with average value of $126.67 \pm 47.8 \mathrm{Pt}-\mathrm{Co}$ in the River Lepmassoun and 135.67 \pm 89.27 Pt-Co in the River Ondomedza. However these values of turbidity recorded in the two rivers are in the standard $(<35, \mathrm{~g} / \mathrm{L})$. neutrality. Their $\mathrm{pH}$ significantly varied from one season to another ranging between 6.66 CPU (Lma1, PSS) and 7.57 UC (Lma2, GSP) in the river Lepmassoun. River Odoamedza had a small variation in $\mathrm{pH}$ ranging between 5.25 UC and 7.97 UC (6.66 $\pm 0.75 \mathrm{CPU})$. The curve of conductivity curve and the TDS are stacking and confirms the positive strong correlation between the two parameters. Conductivity and TDSONT significantly varied on the temporal level in our two rivers. In Lepmassoun the smallest values of conductivity $(22 \mu \mathrm{S} / \mathrm{cm})$ and TDS $(11 \mathrm{mg} / \mathrm{l}))$ are recorded in Lma3 during GSP and the maximum values are observed in Lma2 during the great dry season $(49 \mu \mathrm{S} / \mathrm{cm}$ for conductivity and $25 \mathrm{mg} / \mathrm{l}$ for the TDS) with the averages of conductivity and TDS of $36,47 \pm 8.25 \mu \mathrm{S} / \mathrm{cm}$ and $18.27 \pm 4.26 \mathrm{mg} / \mathrm{l}$ respectively. In the river Ondoamedza, conductivity varied from 14 (Ond3-GSP) to $138 \mathrm{mg} / \mathrm{l}$ (Ond3-PSP) and the TDS varied from 7 to 69 $\mu \mathrm{S} / \mathrm{cm}$. The percentage of oxygen significantly did not vary on the spatiotemporal plan according to the test of Mann Whitney in the river Ondomedza with an average of $62 \pm 0,85 \%$, however in the river Lepmassoun it varied from 60 (Lma2- PSS) to 69.9 (Lma3-GSS 2018). The profile of variation of the dissolved oxygen contents when superimposed with that of the percentage of oxygen in the river Lepmassoun it varied from 4.78 (Lma3-GSP) to 6.75 $\mathrm{mg} / 1$ (Lma3- GSS 2018). However, it is of $4.30 \pm 1.25 \mathrm{mg} / \mathrm{l}$ in the river Ondoamedza. The dissolved $\mathrm{CO}_{2}$ rate and alkalinity significantly varied among the sampling campaign to the other according to the test of Mann
Withney. Thus the $\mathrm{CO}_{2}$ rate varies from $1.76 \mathrm{mg} / \mathrm{l}$ (PSP) to $102.08 \mathrm{mg} / \mathrm{l}$ (GSS 2017) in the river Lepmassoun whereas in the river Ondoamedza it varies from $1.76 \mathrm{mg} / \mathrm{l}$ (Ond2 - PSP) to $133.76 \mathrm{mg} / \mathrm{l}$ (Ond3-GSS 2017). Alkalinity also varied from $2 \mathrm{mg} / \mathrm{l}$ (GSS 2017) to $20 \mathrm{mg} / \mathrm{l}$ (GSS 2018) in Lepmassoun. In the river Ondoamedza the highest values of alkalinity $(48 \mathrm{mg} / \mathrm{l})$ were recorded at the Ond3 station during the PSS and the low values were observed in Ond2 during the GSS 2017 ( $1 \mathrm{mg} / \mathrm{l})$. In Lepmassoun, the maximum $\mathrm{NO}_{3}$ values and $\mathrm{NH}_{4}{ }^{+}$ recorded at the Lma3 station are of $3.7 \mathrm{mg} / \mathrm{l}$ and $0.67 \mathrm{mg} / \mathrm{l}$ respectively and the minimal values of $0.05 \mathrm{mg} / \mathrm{l}$ (GSP) and $0.14 \mathrm{mg} / \mathrm{l}$ (GSP) respectively are recorded as Lma1 and Lma2. In the river Ondoamedza the minimal values of $\mathrm{NO}_{3}$ and that of the $\mathrm{NH}_{4}{ }^{+}$are of $0 \mathrm{mg} / 1$ (Ond1 and Ond 3 during the GSS 2018) and $0 \mathrm{mg} / \mathrm{l}$ (Ond2 - GSS 2018) respectively and the maximum values of $\mathrm{NO}_{3}$ and $\mathrm{NH}_{4}{ }^{+}$ are of $0.5 \mathrm{mg} / \mathrm{l}$ (Ond3-PSS) and $2.1 \mathrm{mg} / \mathrm{l}$ (Ond3-PSP) respectively. The test of Mann Whitney showed a significant difference in nitrate values of between the GSS 2017 and the GSP, the PSP and GSS 2018 and between the PSS and GSP. The contents orthophosphate vary from $0.1 \mathrm{mg} / 1$ (Lma2- PSP) to $4.36 \mathrm{mg} / 1$ (Lma1- GSS 2017 ) in the river Lepmassoun. The curve of variation of the contents orthophosphate is three-phase in the river Ondoamedza. It presents three peaks, the first $(3.7 \mathrm{mg} / \mathrm{l})$ was recorded in Ond1 (PSP), the second peak $(2.71 \mathrm{mg} / \mathrm{l})$ is observed in Ond2 during the PSP and the third peak (2.54 $\mathrm{mg} / \mathrm{l})$ is recorded at the Ond3 station during the PSP. Calcic hardness significantly varied from one campaign to another. It however varies from $0.06 \mathrm{mg} / \mathrm{l}$ (Lma3- PSS) to $2.27 \mathrm{mg} / \mathrm{l}$ (Lma3- GSP) in the river Lepmassoun and in river Ondoamedza it varied from 0.04 $\mathrm{mg} / \mathrm{l}$ (Ond1-GSS 2017 and GSS 2018) to $0.08 \mathrm{mg} / \mathrm{l}$ (Ond3- GSP). 


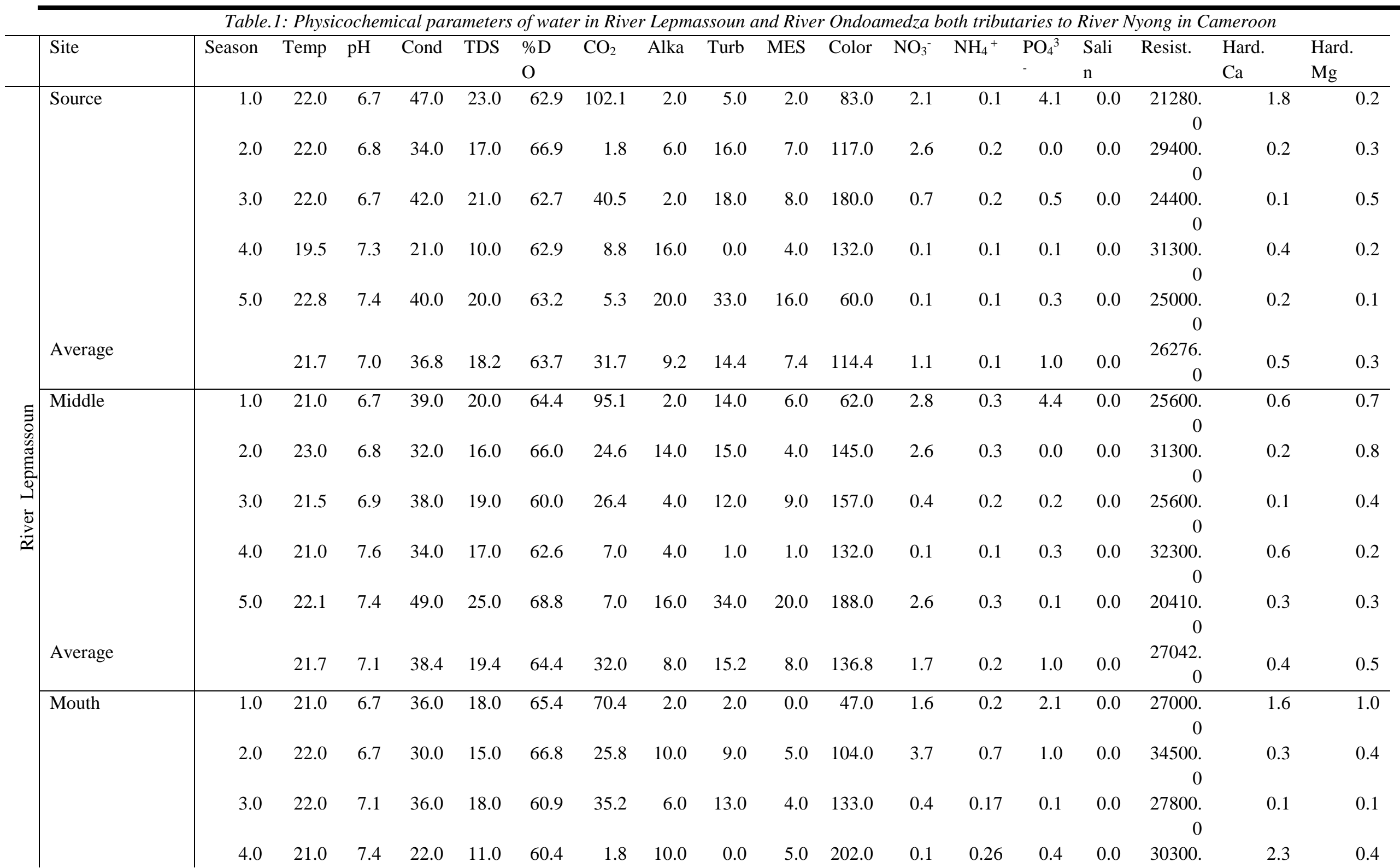




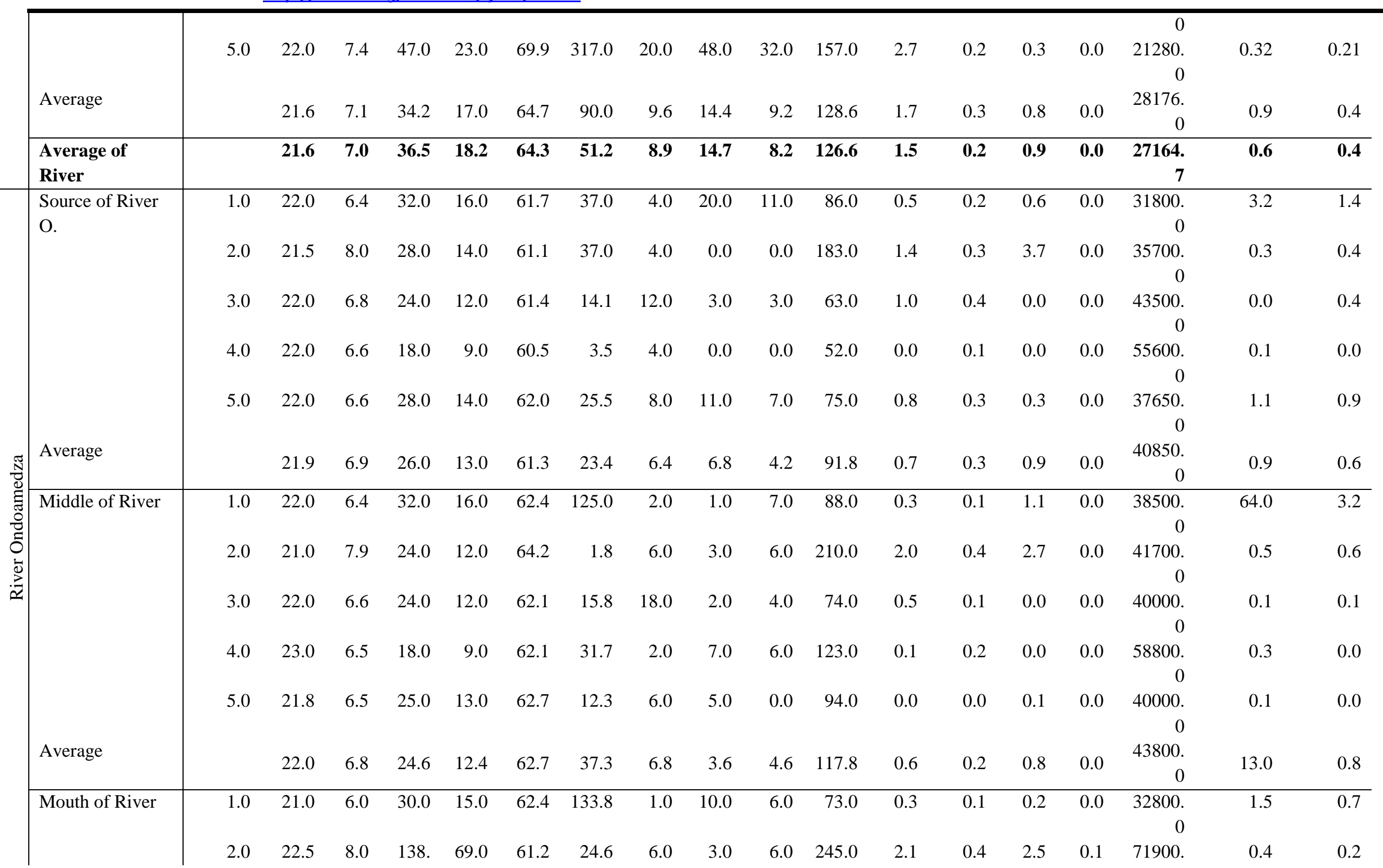




\begin{tabular}{|c|c|c|c|c|c|c|c|c|c|c|c|c|c|c|c|c|c|c|}
\hline & & & & 0 & & & & & & & & & & & & 0 & & \\
\hline & 3.0 & 22.0 & 6.2 & 24.0 & 12.0 & 62.3 & 5.3 & 48.0 & 13.0 & 15.0 & 362.0 & 1.4 & 0.5 & 0.0 & 0.0 & $\begin{array}{r}41700 . \\
0\end{array}$ & 0.1 & 0.1 \\
\hline & 4.0 & 24.0 & 5.3 & 14.0 & 7.0 & 61.6 & 31.7 & 6.0 & 3.0 & 5.0 & 223.0 & 0.1 & 0.5 & 0.0 & 0.0 & $\begin{array}{r}65700 . \\
0\end{array}$ & 0.9 & 0.1 \\
\hline & 5.0 & 21.0 & 6.3 & 32.0 & 16.0 & 62.5 & 12.3 & 20.0 & 14.0 & 0.0 & 84.0 & 0.0 & 0.1 & 0.1 & 0.0 & $\begin{array}{r}32300 . \\
0\end{array}$ & 0.2 & 0.0 \\
\hline & & 22.1 & 6.4 & 47.6 & 23.8 & 62.0 & 41.5 & 16.2 & 8.6 & 6.4 & 197.4 & 0.8 & 0.3 & 0.6 & 0.0 & $\begin{array}{r}48880 . \\
0\end{array}$ & 0.6 & 0.2 \\
\hline $\begin{array}{l}\text { Average of } \\
\text { River }\end{array}$ & & 22.0 & 6.7 & 32.7 & 16.4 & 62.0 & 34.1 & 9.8 & 6.3 & 5.1 & 135.7 & 0.7 & 0.2 & 0.8 & 0.0 & $\begin{array}{r}44510 . \\
0\end{array}$ & 4.9 & 0.5 \\
\hline $\begin{array}{l}\text { (uatic standards } \\
\text { EDD and AE } \\
\text { 03), (NQS 2007), } \\
\text { EQ-EAU, MEDD } \\
\text { al. 2013) }\end{array}$ & & - & $\begin{array}{r}6.5 \\
- \\
9.0\end{array}$ & $\begin{array}{r}2500 \\
- \\
3000\end{array}$ & & $\begin{array}{l}70- \\
90\end{array}$ & & & $\begin{array}{r}15- \\
35\end{array}$ & $\begin{array}{r}25- \\
50\end{array}$ & 50-58 & $2-10$ & $\begin{array}{r}0.1- \\
0.5\end{array}$ & $\begin{array}{r}0.1- \\
0.5\end{array}$ & & & & \\
\hline
\end{tabular}




\section{Biological variables}

\section{Specific composition}

During this study, a total of 113 shrimps was collected set out again in 14 species.40 specimens were recorded in the river Lepmassoun and 73 ispecimes in the river Ondoamedza (Table II). In the river Lepmassoun we collected 10 species set out again by order of predominance as follows Macrobrachium macrobrachion (22,5\%), Macrobrachium spl (20\%) Macrobrachium dux (12,5\%) Macrobrachium sp4 (5\%), Macrobrachium sp5 (5\%) and Macrobrachium sp6 (5\%), Macrobrachium sp9 (5\%), Macrobrachium niloticus (2,5\%)and Macrobrachium rude $(2,5 \%)$. In the river Odoameza 11 species were collected, Macrobrachium sp $8(26,02 \%)$ is abundant pus, followed respectively of Macrobrachium idea (19, $18 \quad \%), \quad$ Macrobrachium sp1 $(16,44 \%)$, Macrobrachium $\quad \mathrm{sp} 7 \quad(9,59 \quad \%)$, from Macrobrachium sp2 (8, 22\%), Macrobrachium sp4 $(6,85 \%)$, Macrobrachium macrobrachion (5,48\%), hard
Macrobrachium (2,74\%), Macrobrachium niloticus (1,37\%), Macrobrachium sp5 (1,37\%) and Macrobrachium sp6(1,37\%).According to the test of Kruskal wallis, in the river Ondomedza all the species did not significantly vary on the plan spatiotemperal. However in the river Lepmassoun, Macrobrachium macrobrachion varied from one season to another. The quantity of Macrobrachium macrobrachion varied from O(GSP) to 6 individuals (GSS 2017).

The index of Shannon and Weaver in the river Lepmassoun is of 2.05 bit/individual and that of Piélou is 0.57. These indices varied respectively in this river of 1.06 (Lma1) to 2.17 Bit (Lma 3) and 0.29 to 0.61. In the river Ondomedza these indices are 2.94 bit/individual and 0.87 respectively. The index of Shannon and the equitability of Piélou varied from $0 \mathrm{bit} /$ individual (Ond1) to $2.83 \mathrm{bit} /$ individual (Ond2) and from 0 to 0.17 respectively.

Table.2:Dynamics of abundances of the genus Macrobrachium (M.) collected for the period of study.

\begin{tabular}{|c|c|c|c|c|c|c|c|c|c|c|c|c|c|c|c|c|}
\hline Stations & Seasons & $\begin{array}{l}\text { M. } \\
\text { macrobrachion }\end{array}$ & M. niloticus & M. $d u x$ & M. rude & M. idea & M. spl & M. sp2 & M. sp3 & M.sp4 &.$M \operatorname{sp} 5$ & M. sp6 & $\begin{array}{l}. \\
p 7\end{array}$ & $\begin{array}{l}M . \\
\text { sp8 }\end{array}$ & $\begin{array}{l}M . \\
\operatorname{sp} 9\end{array}$ & total \\
\hline \multirow[t]{6}{*}{ Lpm1 } & GSS 2017 & 0 & 0 & 0 & 0 & 0 & 0 & 2 & 0 & 0 & 0 & 0 & 0 & 0 & 1 & 3 \\
\hline & PSP & 0 & 0 & 0 & 0 & 0 & 0 & 0 & 0 & 0 & 0 & 0 & 0 & 0 & 0 & 0 \\
\hline & PSS & 0 & 0 & 0 & 0 & 0 & 0 & 0 & 0 & 0 & 0 & 0 & 0 & 0 & 0 & 0 \\
\hline & GSP & 0 & 0 & 0 & 0 & 0 & 0 & 0 & 0 & 0 & 0 & 0 & 0 & 0 & 0 & 0 \\
\hline & GSS 2018 & 2 & 1 & 0 & 0 & 0 & 1 & 0 & 0 & 0 & 0 & 0 & 0 & 0 & 1 & 5 \\
\hline & TOTAL & 2 & 1 & 0 & 0 & 0 & 1 & 2 & 0 & 0 & 0 & 0 & 0 & 0 & 2 & 8 \\
\hline \multirow[t]{6}{*}{ Lpm2 } & GSS 2017 & 2 & 0 & 2 & 0 & 0 & 0 & 0 & 0 & 0 & 0 & 0 & 0 & 0 & 2 & 6 \\
\hline & PSP & 1 & 0 & 0 & 0 & 0 & 0 & 0 & 0 & 0 & 1 & 0 & 0 & 0 & 0 & 2 \\
\hline & PSS & 0 & 0 & 0 & 0 & 0 & 0 & 0 & 0 & 1 & 0 & 0 & 0 & 0 & 0 & 1 \\
\hline & GSP & 0 & 0 & 0 & 0 & 0 & 0 & 0 & 0 & 0 & 0 & 0 & 0 & 0 & 0 & 0 \\
\hline & GSS 2018 & 0 & 0 & 0 & 0 & 0 & 0 & 0 & 1 & 0 & 0 & 0 & 0 & 0 & 0 & 1 \\
\hline & TOTAL & 3 & 0 & 2 & 0 & 0 & 0 & 0 & 1 & 1 & 1 & 0 & 0 & 0 & 2 & 10 \\
\hline \multirow[t]{6}{*}{ Lpm3 } & GSS 2017 & 2 & 0 & 1 & 0 & 0 & 0 & 0 & 0 & 0 & 0 & 0 & 0 & 0 & 2 & 5 \\
\hline & PSP & 1 & 0 & 0 & 1 & 0 & 0 & 0 & 0 & 0 & 0 & 0 & 0 & 0 & 0 & 2 \\
\hline & PSS & 0 & 0 & 2 & 0 & 0 & 2 & 0 & 0 & 1 & 0 & 0 & 0 & 0 & 0 & 5 \\
\hline & GSP & 0 & 0 & 0 & 0 & 0 & 0 & 0 & 1 & 0 & 0 & 0 & 0 & 0 & 0 & 1 \\
\hline & GSS2017 & 1 & 0 & 0 & 0 & 0 & 5 & 0 & 1 & 0 & 1 & 0 & 1 & 0 & 0 & 9 \\
\hline & TOTAL & 4 & 0 & 3 & 1 & 0 & 7 & 0 & 2 & 1 & 1 & 0 & 1 & 0 & 2 & 22 \\
\hline \multirow[t]{6}{*}{ Ond1 } & GSS 2017 & 0 & 0 & 0 & 0 & 0 & 0 & 0 & 0 & 0 & 0 & 0 & 0 & 7 & 0 & 7 \\
\hline & PSP & 0 & 0 & 0 & 0 & 0 & 0 & 0 & 0 & 0 & 0 & 0 & 0 & 0 & 0 & 0 \\
\hline & PSS & 0 & 0 & 0 & 0 & 0 & 0 & 0 & 0 & 0 & 0 & 0 & 0 & 0 & 0 & 0 \\
\hline & GSP & 0 & 0 & 0 & 0 & 0 & 0 & 0 & 0 & 0 & 0 & 0 & 0 & 0 & 0 & 0 \\
\hline & GSS2018 & 0 & 0 & 0 & 0 & 0 & 0 & 0 & 0 & 0 & 0 & 0 & 0 & 9 & 0 & 9 \\
\hline & TOTAL & 0 & 0 & 0 & 0 & 0 & 0 & 0 & 0 & 0 & 0 & 0 & 0 & 16 & 0 & 16 \\
\hline \multirow[t]{3}{*}{ Ond 2} & GSS 2017 & 2 & 0 & 0 & 0 & 9 & 5 & 6 & 0 & 3 & 0 & 0 & 0 & 2 & 0 & 27 \\
\hline & PSP & 0 & 1 & 0 & 1 & 0 & 0 & 0 & 0 & 0 & 1 & 0 & 0 & 0 & 0 & 3 \\
\hline & PSS & 0 & 0 & 0 & 0 & 0 & 0 & 0 & 0 & 0 & 0 & 0 & 0 & 1 & 0 & 1 \\
\hline
\end{tabular}




\begin{tabular}{|c|c|c|c|c|c|c|c|c|c|c|c|c|c|c|c|c|}
\hline & GSP & 0 & 0 & 0 & 0 & 0 & 0 & 0 & 0 & 0 & 0 & 0 & 0 & 0 & 0 & 0 \\
\hline & GSS 2018 & 0 & 0 & 0 & 1 & 0 & 0 & 0 & 0 & 0 & 0 & 0 & 0 & 0 & 0 & 1 \\
\hline & TOTAL & 2 & 1 & 0 & 2 & 9 & 5 & 6 & 0 & 3 & 1 & 0 & 0 & 3 & 0 & 32 \\
\hline \multirow[t]{6}{*}{ Ond3 } & GSS 2017 & 0 & 0 & 0 & 0 & 4 & 1 & 0 & 0 & 0 & 0 & 0 & 0 & 0 & 0 & 5 \\
\hline & PSP & 0 & 0 & 0 & 0 & 0 & 0 & 0 & 0 & 0 & 0 & 0 & 0 & 0 & 0 & 0 \\
\hline & PSS & 0 & 0 & 0 & 0 & 3 & 1 & 0 & 0 & 2 & 0 & 0 & 7 & 0 & 0 & 13 \\
\hline & GSP & 0 & 0 & 0 & 0 & 0 & 0 & 0 & 0 & 0 & 0 & 0 & 0 & 0 & 0 & 0 \\
\hline & GSS 2018 & 1 & 0 & 0 & 0 & 0 & 5 & 0 & 0 & 0 & 0 & 1 & 0 & 0 & 0 & 7 \\
\hline & total & 1 & 0 & 0 & 0 & 7 & 7 & 0 & 0 & 2 & 0 & 1 & 7 & 0 & 0 & 25 \\
\hline
\end{tabular}

\section{Longitudinal distribution}

Generally, the species Macrobrachium macrobrachion, Macrobrachium sp2 and Macrobrachium sp1, Macrobrachium sp4, Macrobrachium sp5 are most present in our basin with the following percentages of presence of occurrence $(\% \mathrm{O})$ respective of $83,33 \%$, $66.67 \%, 60 \%$ and $50 \%$ (Table III). The species Macrobrachium macrobrachion is most ubiquiste throughout river Lepmassoun $(\% \mathrm{O}=100 \%)$ that the other species like Macrobrachium sp1 (66.67\%,), Macrobrachium sp3 (66.67\%),Macrobrachium sp4 (66.67\%), Macrobrachium sp5 (66.67\%), Macrobrachium sp9 (66.67\%), Macrobrachium niloticus $(\% \mathrm{O}=33.33 \%$, Macrobrachium rude $(\% \mathrm{O}=33.33)$, and Macrobrachium sp7 $(\% \mathrm{O}=33.33 \%)$ are secondary represented along the gradient upstream downstream. In the river Ondoameza Macrobrachium sp8, Macrobrachium idea, Macrobrachium macrobrachion,Macrobrachium sp4 having all the percentage of occurrence $(\% \mathrm{O})$ of $66.67 \%$ are relatively represented throughout river as for the other species of which the percentage of presence is inferior with $50 \%$ $(\% \mathrm{O}=33,33 \%)$, they are regularly present from upstream to downstream of the river.

Table.3: percentage of occurrence $(\% O)$ of genus Macrobrachium in our basin

\begin{tabular}{|l|r|r|r|}
\hline & si & st & $0 \%$ \\
\hline M. & 5 & & \\
macrobrachion & 2 & 6 & 83,3333333 \\
\hline M. niloticus & 2 & 6 & 33,3333333 \\
\hline M. rude & 2 & 6 & 33,3333333 \\
\hline M. idea & 3 & 5 & 60 \\
\hline M. sp1 & 4 & 6 & 66,6666667 \\
\hline M.sp2 & 1 & 6 & 16,6666667 \\
\hline M. sp3 & 3 & 6 & 50 \\
\hline M. sp4 & 3 & 6 & 50 \\
\hline M. sp5 & 1 & 6 & 16,6666667 \\
\hline M. sp6 & 2 & 6 & 33,3333333 \\
\hline M. sp7 & & & \\
\hline
\end{tabular}

\begin{tabular}{|l|l|l|l|} 
M. sp8 & 2 & 6 & 33,3333333 \\
\hline M. sp9 & 2 & 6 & 33,3333333 \\
\hline
\end{tabular}

Influence of environmental factors on crustacean distribution

Relationship between abiotic parameters and the shrimp community

According to the correlations of SPEARMAN, conductivity is correlated positively and significantly with the TDS $(\mathrm{R}=0.563 ; \mathrm{p}=0.01)$, oxygen $(\mathrm{R}=0.676 ; \mathrm{p}=$ $0.01)$, turbidity $(\mathrm{R}=0.563 ; \mathrm{p}=0.01)$. However it negatively correlated with the resistivity $(\mathrm{R}=-0.695$, $\mathrm{p}=0.01)$. MES of course are correlated positively with turbidity $(\mathrm{R}=0.641) ; \mathrm{p}=0.01)$. The resistivity as for it negatively correlated with turbidity $((\mathrm{R}=-0.526 ; \mathrm{p}=0.01)$ and the TDS $(\mathrm{R}=-0.694 ; \mathrm{p}=0.01)$. The $\mathrm{pH}$ correlated positively with calcic hardness $(\mathrm{R}=0.512 ; \mathrm{p}=0.01)$. The ammoniacal nitrogen correlated positively with the color $(\mathrm{R}=0.540 ; \mathrm{p}<0.01)$ and negatively with magnesic hardness $(\mathrm{R}=-0.623 ; \mathrm{p}=0.01)$. Oxygen negatively correlated with the carbon dioxide $(\mathrm{R}=-0.573 ; \mathrm{p}=0.01)$ and positively with the temperature $(\mathrm{R}=0.553 ; \mathrm{p}=$ $0.01)$. The contents nitrate strongly correlated with magnesic hardness $(\mathrm{R}=0.623 ; \mathrm{p}=0.01)$. As regards the relations existing between the shrimp species and the parameters abiotic (Table III) shows that Macrobrachium macrobrachion significantly and positively correlated with the percentage of oxygen, However this species negatively correlated with the resistivity and the color. Macrobrachium dux negatively correlated with $\mathrm{CO} 2$, , Macrobrachium sp2 negatively correlated with the hardness magnesic, the The species Macrobrachium rude and Macrobrachium niloticus, , Macrobrachium sp3, Macrobrachium sp4, $M$ sp7 significantly correlated with no physico-chemical parameter. Macrobrachium idea negatively correlated with the $\mathrm{pH}$, Macrobrachium sp3 negatively correlated with dissolved $\mathrm{CO}_{2}$ and the resistivity. The species Macrobrachium sp5 positively correlated with the percentage of saturation out of $\mathrm{O}_{2}$. As regards Macrobrachium sp7, it has significantly and positively correlated with MEs,alkalinity and the conductivity and finally Macrobrachium sp 8 positively 
correlated with magnesic hardness. Macrobrachium sp9 positively correlated with the alkalinity

An Analysis in Principal Components (ACP) is made thereafter to determine the physico-chemical parameters characteristic of the various formed groups. The analyzed matrix is a table of 19 columns corresponding to the environmental parameters taken into account and 30 lines representing the samples taken in the 6 stations of sampling during the 5 study campaigns. The essence of the original variance is provided on the first 5 factorial axes F1 (24.05\%) and F2 (19.38 \%), F3 (15.55 $\%)$, F4 (10.73\%) and F5 (9.009\%) which cumulate
$63.31 \%$ of total inertia (Figure 2b). The variable like Macrobrachium sp1, Macrobrachium sp3, the calcic hardness one, $\mathrm{CO}_{2}$ and Macrobrachium sp4 are more negatively correlated known the axis F1; however on turbidity, Macrobrachium sp2, the percentage of oxygen and nitrate are correlated positively on the axis F2. On the axis F3, conductivity, orthophosphates, the TDS and salinity is correlated there positively. The species Macrobrachium sp7, alkalinity and the color are positively correlated on the axis hard F4. Finally Macrobrachium sp8and the ammoniacal nitrogen are positively correlated on the axis F5

Table.4: Spearman correlation between Macrobrachium shrimp abundance and physicochemical parameters

\begin{tabular}{|c|c|c|c|c|c|c|c|c|c|c|c|c|c|c|c|}
\hline Parameters & & $\begin{array}{c}M . \\
\text { macrobrach } \\
\text { ion }\end{array}$ & $\begin{array}{c}\text { M. } \\
\text { nilotic } \\
\text { us } \\
\end{array}$ & $\begin{array}{c}M . d \\
u x\end{array}$ & $\begin{array}{c}\text { M.ru } \\
d e\end{array}$ & $\begin{array}{c}\text { M.sp } \\
8\end{array}$ & $\begin{array}{c}\text { M.id } \\
e a\end{array}$ & $\begin{array}{c}M . s p \\
1\end{array}$ & $\begin{array}{c}\text { M.sp } \\
2\end{array}$ & $\begin{array}{c}M . s p \\
3\end{array}$ & $\begin{array}{c}M . s p \\
4\end{array}$ & $\begin{array}{c}M . s p \\
5\end{array}$ & $\begin{array}{c}M . s p \\
6\end{array}$ & $\begin{array}{c}M . s p \\
7\end{array}$ & $\begin{array}{c}M s p \\
9\end{array}$ \\
\hline \multirow{3}{*}{ pH (UC) } & e &,- 055 & ,332 & ,009 & ,064 & $\begin{array}{r}- \\
, 352\end{array}$ & $\begin{array}{r}- \\
, 459^{*}\end{array}$ & $\begin{array}{r}- \\
, 196\end{array}$ & $\begin{array}{r}- \\
, 159\end{array}$ & ,347 & $\begin{array}{r}- \\
, 165\end{array}$ & ,315 & $\begin{array}{r}- \\
, 247\end{array}$ & ,035 & 043 \\
\hline & $\mathrm{p}$ & ,774 & ,073 & ,964 & ,736 & ,056 & ,011 & ,300 & ,400 & ,061 & ,384 & ,090 & ,189 & ,856 & ,823 \\
\hline & $\mathrm{N}$ & 30 & 30 & 30 & 30 & 30 & 30 & 30 & 30 & 30 & 30 & 30 & 30 & 30 & 30 \\
\hline \multirow{3}{*}{$\begin{array}{l}\text { conductivity }(\mu \mathrm{S} / \\
\mathrm{cm})\end{array}$} & e & ,334 & ,023 & ,265 &,- 200 & $\begin{array}{r}- \\
, 109\end{array}$ &,- 108 &, 194 &, 195 & , 193 &, 062 & ,064 &, 022 & $\begin{array}{r}, 403 \\
*\end{array}$ & ,052 \\
\hline & $\mathrm{p}$ & ,071 & ,903 &, 158 & ,290 & ,567 & ,570 & ,305 & 301 & 307 & ,747 &, 735 & ,910 & ,027 & ,787 \\
\hline & $\mathrm{N}$ & 30 & 30 & 30 & 30 & 30 & 30 & 30 & 30 & 30 & 30 & 30 & 30 & 30 & 30 \\
\hline \multirow{3}{*}{ TDS (mg/L) } & e & ,331 & ,015 & ,271 &,- 200 & $\begin{array}{r}- \\
, 109 \\
\end{array}$ &,- 108 &, 185 & ,203 &, 187 &, 062 & ,058 &, 022 & $\begin{array}{r}409 \\
*\end{array}$ & ,044 \\
\hline & $\mathrm{p}$ & ,074 & ,935 &, 147 & ,290 &, 567 &, 570 & ,328 & ,282 & ,323 & ,747 & ,761 & ,910 & ,025 &, 817 \\
\hline & $\mathrm{N}$ & 30 & 30 & 30 & 30 & 30 & 30 & 30 & 30 & 30 & 30 & 30 & 30 & 30 & 30 \\
\hline \multirow{3}{*}{ Percent O2(“\%) } & e &, $505^{* *}$ & ,216 &, 074 & ,283 & $\begin{array}{r}- \\
, 209 \\
\end{array}$ &,- 056 &, 063 &, 059 &, 186 & $\begin{array}{r}- \\
316 \\
\end{array}$ & $\begin{array}{r}417 \\
*\end{array}$ &, 011 & ,338 & , 176 \\
\hline & $\mathrm{p}$ &, 004 &, 251 & ,698 &, 130 & ,268 &, 767 & ,741 & ,758 & ,324 &, 089 & ,022 & ,955 & ,067 & ,351 \\
\hline & $\mathrm{N}$ & 30 & 30 & 30 & 30 & 30 & 30 & 30 & 30 & 30 & 30 & 30 & 30 & 30 & 30 \\
\hline \multirow[t]{3}{*}{$\mathrm{CO} 2(\mathrm{mg} / \mathrm{L})$} & e & , 162 &,- 348 & $\begin{array}{r}365 \\
*\end{array}$ &,- 193 & ,244 & ,263 &, 011 & $\begin{array}{r}402 \\
*\end{array}$ & $\begin{array}{r}411 \\
*\end{array}$ &, 168 &, 321 & ,086 & ,302 &, 315 \\
\hline & $\mathrm{p}$ &, 393 & ,060 & ,048 & 307 & ,193 &, 160 & ,955 & ,028 & ,024 & ,374 & ,083 & ,652 &, 104 &, 090 \\
\hline & $\mathrm{N}$ & 30 & 30 & 30 & 30 & 30 & 30 & 30 & 30 & 30 & 30 & 30 & 30 & 30 & 30 \\
\hline \multirow{3}{*}{$\begin{array}{l}\text { Alkalinity } \\
(\mathrm{mg} / \mathrm{L})\end{array}$} & e & ,081 & , 195 & ,280 &, 065 &, 034 &,- 165 & ,243 &, 343 & ,344 &, 026 & ,260 & ,271 &, $252^{-}$ & $\begin{array}{r}422 \\
*\end{array}$ \\
\hline & $\mathrm{p}$ & ,672 & ,302 &, 133 & ,733 & 857 & ,385 & ,195 & ,063 & ,063 & ,893 & ,166 &, 147 & ,179 &, 020 \\
\hline & $\mathrm{N}$ & 30 & 30 & 30 & 30 & 30 & 30 & 30 & 30 & 30 & 30 & 30 & 30 & 30 & 30 \\
\hline \multirow{3}{*}{ MES (mg/L) } & e &, 055 & ,233 &, 184 &,- 149 & ,225 & ,260 &, 250 &, 023 & ,342 & ,264 &, 155 &, 270 & $\begin{array}{r}- \\
, 079 \\
\end{array}$ & $\begin{array}{r}, 402 \\
*\end{array}$ \\
\hline & $\mathrm{p}$ & ,775 & 215 & ,331 & ,433 & ,232 &, 165 &, 182 & ,903 &, 064 &, 158 & ,413 & , 149 & ,679 &, 028 \\
\hline & $\mathrm{N}$ & 30 & 30 & 30 & 30 & 30 & 30 & 30 & 30 & 30 & 30 & 30 & 30 & 30 & 30 \\
\hline \multirow[t]{3}{*}{ color $(\mathrm{mg} / \mathrm{L})$} & e &,$- 384^{*}$ &,- 015 & 280 & ,096 &, 270 &, 004 &, 058 &, 153 & ,334 & ,226 & ,282 &, 118 & \begin{tabular}{l|l}
- \\
, 514 \\
$* *$
\end{tabular} &, 321 \\
\hline & $\mathrm{p}$ & ,036 & ,935 & ,135 &, 613 &, 149 & ,984 &, 762 &, 420 &, 071 &, 230 &, 130 &, 534 & ,004 & ,084 \\
\hline & $\mathrm{N}$ & 30 & 30 & 30 & 30 & 30 & 30 & 30 & 30 & 30 & 30 & 30 & 30 & 30 & 30 \\
\hline nitrate $(\mathrm{mg} / \mathrm{L})$ & e & ,249 & ,000 & ,205 &, 090 &, 058 &,- 085 &, 152 &, 040 & , 199 & $\begin{array}{r}- \\
, 079 \\
\end{array}$ & $\begin{array}{r}379 \\
*\end{array}$ & $\begin{array}{r}- \\
, 301 \\
\end{array}$ & ,245 & ,251 \\
\hline
\end{tabular}




\begin{tabular}{|c|c|c|c|c|c|c|c|c|c|c|c|c|c|c|c|}
\hline & $\mathrm{p}$ & , 185 & 1,000 & ,277 & ,636 & ,761 & ,656 & ,422 &, 835 & ,291 & ,679 & ,039 & ,106 & , 192 &, 182 \\
\hline & $\mathrm{N}$ & 30 & 30 & 30 & 30 & 30 & 30 & 30 & 30 & 30 & 30 & 30 & 30 & 30 & 30 \\
\hline \multirow{3}{*}{$\begin{array}{l}\text { orthophossphate } \\
\text { (mg/L) }\end{array}$} & e & , 280 & , 224 & ,233 & 206 & , 111 &,- 017 & ,061 & ,337 & (058 & ,069 & ,019 & , 140 & $\begin{array}{r}464 \\
* *\end{array}$ & , 107 \\
\hline & $\mathrm{p}$ & ,135 & ,233 & ,215 & ,275 & ,558 & ,930 & ,748 & ,068 & ,761 & ,718 & ,919 & ,462 & ,010 & ,574 \\
\hline & $\mathrm{N}$ & 30 & 30 & 30 & 30 & 30 & 30 & 30 & 30 & 30 & 30 & 30 & 30 & 30 & 30 \\
\hline \multirow{3}{*}{ salinity(PSU) } & e & ,114 & ( & ,400 &,- 223 & ,261 &,- 222 & ,039 & ,063 & 193 & , 080 & ,015 & ,360 & $\begin{array}{r}, 470 \\
* *\end{array}$ & , 063 \\
\hline & $\mathrm{p}$ & ,547 & ,708 & ,028 & ,237 & , 163 & ,238 & ,837 & ,741 & ,307 & 674 & ,938 & ,051 & , 009 & ,741 \\
\hline & $\mathrm{N}$ & 30 & 30 & 30 & 30 & 30 & 30 & 30 & 30 & 30 & 30 & 30 & 30 & 30 & 30 \\
\hline \multirow{3}{*}{ resistivity } & e &,- 311 &,- 023 & ,295 & 238 & , 170 & ,202 & , 135 & 106 & ,411 & , 010 & ,090 & ,000 & $\begin{array}{r}447 \\
*\end{array}$ & ,050 \\
\hline & $\mathrm{p}$ & ,095 & 903 & ,113 & 206 & ,370 & 284 & ,476 & ,576 & ,024 & 958 & ,637 & $\begin{array}{r}1,00 \\
0\end{array}$ & ,013 & ,791 \\
\hline & $\mathrm{N}$ & 30 & 30 & 30 & 30 & 30 & 30 & 30 & 30 & 30 & 30 & 30 & 30 & 30 & 30 \\
\hline \multirow{3}{*}{$\begin{array}{l}\text { Hardness calcic } \\
(\mathrm{mg} / \mathrm{L})\end{array}$} & e & , 191 & ,015 & ,046 &,- 129 & ,303 & , 183 & ,059 & ,403 & , 180 & , 186 & ,013 & , 140 & , 290 & , 161 \\
\hline & $\mathrm{p}$ & ,311 & ,935 & ,808 & 498 & ,103 & ,334 & ,758 & ,027 & 341 & ,324 & ,946 & ,462 & , 121 & ,395 \\
\hline & $\mathrm{N}$ & 30 & 30 & 30 & 30 & 30 & 30 & 30 & 30 & 30 & 30 & 30 & 30 & 30 & 30 \\
\hline \multirow{3}{*}{$\begin{array}{l}\text { Hardness } \\
\text { magnésic(mg/l) }\end{array}$} & e & ,249 &,- 046 & , 150 &,- 013 & ,383 & ,236 & , 149 & ,179 & ,006 & , 068 & 206 & ,279 & ,112 & , 134 \\
\hline & $\mathrm{p}$ & ,184 & ,808 & ,429 & ,946 & ,037 & ,209 & ,432 & ,343 & ,973 & ,723 & ,275 & ,135 & ,557 & ,481 \\
\hline & $\mathrm{N}$ & 30 & 30 & 30 & 30 & 30 & 30 & 30 & 30 & 30 & 30 & 30 & 30 & 30 & 30 \\
\hline
\end{tabular}

*. La corrélation est significative au niveau 0,05 (bilatéral).

**. La corrélation est significative au niveau 0,01 (bilatéral).

\section{Reproduction of Macrobrachium dux}

\section{Determination of the sex-ratio and rate of femininity}

All in all, the females are more numerous than the males. During the period of study 5 individuals of Macrobrachium dux were collected either 5 individuals (4 females and 1 males) in the river Lepmassoun giving a sex-ratio of 0.25 . From a campaign to another in the river
Lepmassoun the sex-ratio at this species varied from 0 (PSS) with 0.5 (GSS 2017) and the females are dominant except during the small dry season where the males are equal to the females. Genrally, the rate of feminity (TF) during all the period of study in the river Lepmassoun is $57.14 \%$, it varied from $66,67 \%$ (GSS2017) to $100 \%$ (PSS) ( Table V).

Table.5: Number of males $(M)$, females $(F)$ sampled by campaign and sex-ratio $(\mathrm{Sr})$, and feminity rate $(\mathrm{TF})$

\begin{tabular}{|l|r|r|r|r|r|r|r|}
\hline Macrobrachium mabrachion & F & M & FO & f+m & Sr F & Sr M & TF \\
\hline GSS 2017 & 2 & 1 & 1 & 3 & 0,5 & 2 & 66,67 \\
\hline PSP & 0 & 0 & 0 & 0 & 0 & 0 & \\
\hline PSS & 2 & 0 & 2 & 2 & 0 & 0 & 100 \\
\hline GSP & 0 & 0 & 0 & 0 & 0 & & \\
\hline GSS 2018 & 0 & 0 & 0 & 0 & & & \\
\hline & 4 & 1 & 3 & 5 & 0,25 & 4 & 80 \\
\hline
\end{tabular}

\section{Fruitfulness and gonado-somatic ratio (RGS)}

Three ovigerous females were collected during our study. An ovigerous female was obtained at the Lma3 station during the first countryside, it has a size (LT) of approximately $52 \mathrm{~mm}$ and it weighs (W) $1,79 \mathrm{~g}$ and has an absolute fruitfulness of 39 eggs. The two other ovigerous females were recorded at the Lma3 station during the PSS (Table V).One has a size of approximately $50.38 \mathrm{~mm}$, it weighs $0.176 \mathrm{~g}$ and carries 39 eggs, the other as for it weight of $0.312 \mathrm{~g}$, it has a size of $64.18 \mathrm{~mm}$ and its absolute fruitfulness is of 100 eggs. Average absolute fruitfulness at this species is of 59 eggs. Relative fruitfulness as for it varied from $22 \mathrm{eggs} / \mathrm{g}$ for the female which measures $52 \mathrm{~mm}$ (Lma3-GSS 2017) to $34 \mathrm{eggs} / \mathrm{G}$ for the largest female which measures $64.18 \mathrm{~mm}$, giving an average of $28 \mathrm{eggs} / \mathrm{g}$. The eggs carried by the females are of yellow color orange sharp. Concerning the report/ratio gonado-somatic (RGS), it varied from $4.44 \%$ 
for the female collected in first countryside (GSS 2017) to $12.35 \%$ for the female collected during the third countryside with an average value is $9.11 \%$. The GSI showed highest percentage of mature females $(<50 \%)$ from January 2017 to February 2018. Maxima of GSI
$(10.52 \%)$ were recorded at PSS (July) and minim of GSI $(1.73 \%)$ were recorded during the GSS 2017 (January). The GSI mean is $7.67 \%$ in PSS. This indicates that $M$. dux in Lepmassoun River underwent a reproductive period during the dry season.

Table.5: Absolute fruitfulness (FT), relative fruitfulness (FR), Gonadosommatic report/ratio (RGS) and gonadosomatic index (RGI) at Macrobarchium dux.

\begin{tabular}{|r|r|r|r|l|r|r|r|r|}
\hline $\begin{array}{l}\text { Number of } \\
\text { eggs }\end{array}$ & $\operatorname{Lt}(\mathrm{mm})$ & $\operatorname{Lc}(\mathrm{mm})$ & $\operatorname{Pt}(\mathrm{g})$ & $\begin{array}{l}\mathrm{P}(\mathrm{G}) \\
(\mathrm{g})\end{array}$ & FT(eggs) & FR(eggs/g) & RGS \% & RGI(\%) \\
\hline 39 & 52 & 14.5 & 1.758 & 0.078 & 39 & 22.18 & 4.43 & 1.73 \\
\hline 38 & 50.38 & 11.72 & 1.424 & 0.176 & 39 & 27.19 & 12.35 & 4.82 \\
\hline 100 & 64.18 & 15.14 & 2.963 & 0.312 & 100 & 33.69 & 10.52 & 10.52 \\
\hline
\end{tabular}

Relationship between the number of eggs and morphological parameters at Macrobrachium dux

In our zone of study the coefficient of correlation (R2) are respectively $0.42 ; 0.99$ and 0.96 for the relation which exists between the number of egg and the length of the carapace (Lc) (Figure 2a), then the number of eggs and overall length (Lt) (Figure 2b) and finally the number of egg and weight (w) (Figure 2c).The greatest constant of regression $(\mathrm{a}=42.59)$ is observed in the existing relation between number of egg and Pt, follow-up of that putting forward the number of eggs and Lt $(\mathrm{a}=4.64)$ and finally that connecting the number of eggs and Lc $(a=0.0334)$. As regards the coefficient of regression (b), it is negative for the existing relation between a number of eggs and $\mathrm{Pt}(\mathrm{b}=$ - 28.05) and between the number of eggs and Lt ( $b=-$ 198.55).This coefficient (b) is positive for the existing relation between the number of eggs and Lc. We note that when the female is large it produces more eggs to its advantage.

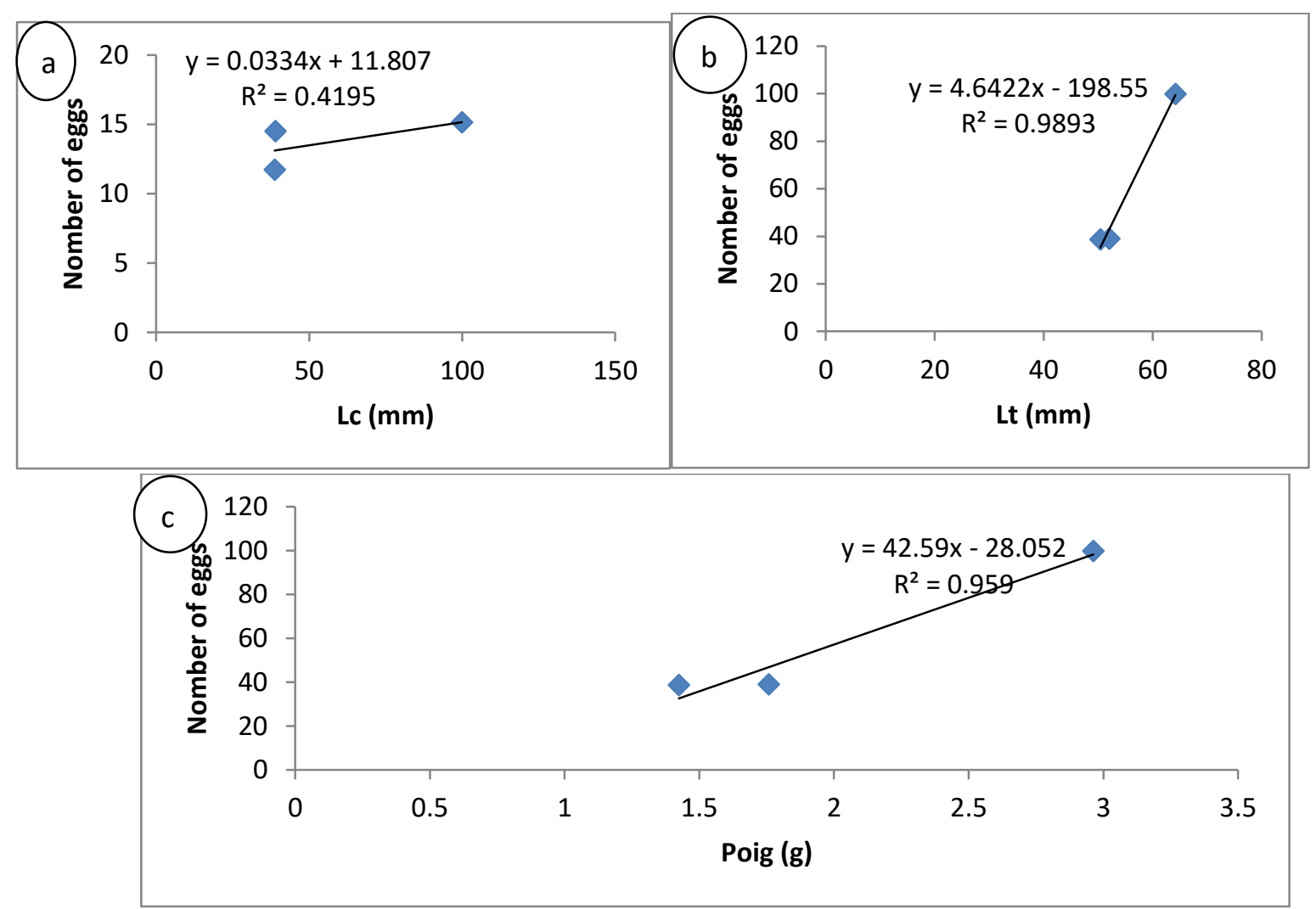

Fig.2: relationship between the number of eggs and Lc (a), the number of eggs and Lt $(b)$ and the number of eggs with weight (c) at Macrobrachium dux 


\section{Environmental variables}

The values of temperature recorded in the river Lepmassoun and Ondoamedza all located in medium rural significantly did not vary from one station to another. This would be explained by the presence of canopée which is present and almost identical to all the stations which constitutes a barrier reducing the penetration of the solar rays on the variation in the temperature of water along the river. This observation is in agreement with those of(Foto Menbohan, Koji et al. 2012) (Foto Menbohan, Mboye et al. 2017)and (Tchakonte, Ajeagah et al. 2014), Biram À Ngon and al..(2018)(BIRAM à NGON, FOTO MENBOHAN et al.) obtained on Nga, Mabounié, Nsapè jets, Abouda, Fam, Nkoumou and Nga respectively. However the variations observed from one season to another in the river Lepmassoun would result from the variation in the temperature during dry seasons. Ebang, 2004 underlines on this subject that the temperature of surface water is strongly influenced by the ambient temperature and the seasons. These values of temperature are favorable to the good biological development (Ouhmidou and al., 2014).The range of the values obtained is located in the range of the temperature of bearable water by the fresh water shrimps which support some until $34^{\circ} \mathrm{C}$ beyond which they are vulnerable (Griessinger and al., 1990).

The low values of conductivity $(34.6 \mathrm{mg} / \mathrm{l})$ obtained during our study in our rivers would be explained by nature slightly anthropized of our various areas catchment and with the nature of the grounds. These results approaches those obtained by Ajeagah and $A l, 2017$ in the river Matourou of the catchment area of Nyong $(25,89 \mathrm{mg} / \mathrm{l})$. The strong value recorded during the PSP means that there exists in this month a great concentration of dissolved electrolysable salts which is explained by the scarcity of the rains. The brutal fall of conductivity during the great season rain is due to arrival of the rains leading to the flood. These values of conductivity $(<35 \mathrm{mg} / \mathrm{l})$ respect the standards of quality of surface water (AE 1999). Light acidity with a tendency of neutrality recorded in the two rivers could be explained by the presence of the humuses resulting from the degradation of the sheets died in our rivers which are under cover vegetal. Welcome (1985) affirms that the forest rivers, with water with humic characteristics rich person in substance, are slightly with strongly acid with a pH located between 4 and 7 UC. These forest rivers are favorable to the development of the watery organizations. According to (AE 1999), the $\mathrm{pH}$ ranging between 6.0 and 8.5 UC is favorable to the expression of the biological potentials of many groups. The low values of my study recorded in the two rivers approaches those recorded by Ajeagah and Al, 2017 in the same ecological area. These results could be explained by the fact that water of the river Lepmassoun and Ondomedza is slightly charged. The values of turbidity $(<35, \mathrm{~g} / \mathrm{l})$ recorded are relatively low and testify to a good ecological quality according to (MEDD and AE 2003). The differences between the campaigns mentioned by the test of $U$ of Mann Withney could be explained by the fact that during the season of rains the particles are suspended thus affecting turbidity.The average values of color observed in our rivers could be explained by the presence of the colloidal particles of negative charge, these result approach work of (Ajeagah, Yogback et al. 2017) carried out in the catchment area of Nyong. Generally, the average values of dissolved oxygen recorded in our different river make it possible to qualify their water of passable with good (Villeneuve, Legare et al. 2006). These oxygen values which we obtained are inferiors with that obtained by Agadjihouede, 2006 in the lagoon of large-popo $(9.76 \mathrm{mg} / \mathrm{l})$ but are acceptable for a good growth of the shrimps (Griessinger, Lacroix et al. 1991) for these authors, with the tops of $5 \mathrm{mg} / \mathrm{l}$, the shrimp is under favorable conditions of breeding. With the lower parts of $2 \mathrm{mg} / \mathrm{l}$, the shrimps cannot balance their needs anymore and die when this content persists. The orthophosphate contents recorded in the river Lepmassoun are relatively weak and significantly varied from one season to another according to the test of Kruskal Wallis $(p<0,05)$.The strong values recorded during the first countryside which corresponds to the great season dries 2017 could be due to the strong mineralization of the organic matter. During this season the river has undergoes a very significant stress hydrous which caused the accumulation of the organic matter (sheets dead) as our rivers are under wood what supports a very thorough mineralisation of the organic matter. The $\mathrm{NH}_{4}{ }^{+}$having increased station Lma1and the Lma3 station in the river Lepmassoun is nevertheless below the standards recommended by the (SEQ-EAU, MEDD et al. 2013) (Table V).This would be in relation to the bacterial decomposition of the nitrogenized organic matter of made light reductions in the contents of $\mathrm{O}_{2}$ dissolved recorded in these periods. Their weak presence in the river Lepmassoun and Ondoamedza could be explained by made that the medium is sufficiently oxygenated. For this purpose (IBGE 2005) stress that it is in absence of oxygen that the anaerobic bacteria transform nitrates and produce ammonia $\left(\mathrm{NH}_{3}\right)$ or ammonium $\left(\mathrm{NH}_{4}{ }^{+)}\right.$. The strong values of nitrate recorded in the river Ondoamedza during the small season of rain could be explained by the scrubbing of the agricultural grounds in the catchment area. Liechti, 2010 underline on this subject which if the contents nitrates exceed $1.5 \mathrm{mg} / \mathrm{L}$, there probably was arable land scrubbing.

\section{Biological variables}


During this study the inventory of shrimps of the genus Macrobrachium made it possible to put forward 14 shrimp species. This specific richness is higher than that obtained by (Tchakonte, Ajeagah et al. 2014) in the river Nsapè in zone périurban of Douala and no species of Macrobrachium is common for us. Our specific richness is also high than that obtain by Makoumbou and al., 2015 in the rivers Lokoundje, Kienke and Lobe Rivers of South Region, Cameroon where we have two species (Macrobrachium macrobrachium and Macrobrachium dux).This difference could be explained by the fact Nsapè , Lokoundje, Kienke and Lobe river are a coastal river and cuts the throat of the coastal species and the land species. Of share the position péri urban, the court of water Nsapé could start to be subject to the influence of the urban activities contrary to our rivers which are located in rural zone where the anthropic activity is quasi null. It is also necessary to note that specific richness of each one of our rivers is higher than that of (Ajeagah, Yogback et al. 2017)in the river Matourou where only one species of Macrobrachium was obtained. This difference would be explained since our rivers are rich in microhabitats contrary to river Matourou. Our specific richness is higher than the specific richness of the genus Macrobrachium (6 species) obtained by (Konan 2009) in seven rivers in Ivory Coast, it is also higher than that obtained in Ivory Coast in the Boubo river (N'zi, B.G. et al. 2008) where nine shrimp species identified and also higher than that is obtained by (Djiriéoulou Kémomadjèhi, Bamba et al. 2017.) in the Forest of the Tanoé-Ehy Marshes in Ivory Coast. This specific difference is explained by the methods of fishing used, the types of sampled habitats and the periods of sampling. Seasonal of the specific richness showed that greater specific richness was recorded for the period of rising. These data show that the living conditions are more favorable for the watery organizations during this period (Djiriéoulou Kémomadjèhi, Bamba et al. 2017.).In our site of study, Macrobrachium macrobrachion $(10,61 \%)$ is not dominating as in work of (Agadjihouede 2006) in the lagoon of large-popo with a percentage higher than our (51\%), but this predominance is not observed by (N'zi, B.G. et al. 2008) in the river Mboumbo and where it is Macrobrachium vollenhovenii which dominates rather, in the river Boubo (N'zi, B.G. et al. 2008) this species is found only in the station which is very well oxygenated contrary to our rivers which are fairly oxygenated. We think that oxygen is a factor discriminating for the presence or not of Macrobrachium Macrobrachion. The under predominance of Macrobrachium macrobrachion in our work is also observed by (Djiriéoulou Kémomadjèhi, Bamba et al. 2017.), where this species is dominated by far in the forest of the Tanoé-Ehy Marshes in Ivory Coast. These observations could be explained by the environmental conditions which more prochoche or similar from the drill of the marsh Tanoé-Ehy water where oxygen is not very good. It is however advisable to underline like Troadec and al. (1967) that the distribution and the abundance of the macro invertebrates like shrimps in the rivers, is on the whole, function of the specific requirements of various taxed and the environmental characteristics with the various portions of the rivers, as well as availability of food and nature of the substrate. As regards the reproduction, absolute fruitfulness had an average of (59 \pm 35 eggs) which we obtained form Macrobrachium dux is less than that brought back by Deeka and Aowei, 2010 (1403 eggs);Eni and al, 2013 (442058 eggs) and Boguhe and al, 2016 (19906 \pm 6640 eggs) for Macrobrachium macrobrachion. this fruitfulness is also less than that found by Kouton (2004) in the valley of Ouémé, by Goore Bi (1998) in the basin of Bia in Côte.d'ivoire and by Agadjihouede, 2006 in the lagoon of Large the popo for the species Macrobrachium macrobrachion. The weak production of eggs by our females compared to the others species could due to the fact that our rivers are less favorable to the development of this species (low depth, raised color, temperature, average oxygenation) compared to the other rivers referred to above. The differences observed could also be allotted to the differences in egg dimension (Beacham and Murray, 1993), the techniques of sampling and the overall length of the female (Deeka and aowei, 2010). In addition, the variations found for fruitfulness can also be due to the differences of environmental conditions, the provisioning food, the seasons and the physiological parameters of environment (Bagenal, 1978) and the physiology of species. Total length of ovigerous females ranged from $50,38 \mathrm{~mm}$ to $64,18 \mathrm{~mm}$ and egg size varied from 1.5 to $1.9 \mathrm{~mm}$. Compared to other species, the eggs of Macrobrachium dux are larger than those of Macrobrachium lanchesteri 0.8-1.0 $\mathrm{mm}$ and Macrobrachium olfersii $0.4-0.6 \mathrm{~mm}$ reported by Hla et al. (2005) but nearly similar to those of M. lamarrei (1.1-1.5 $\mathrm{mm})$ reported by the same authors and nearly similar to the same species in river Orogodo in Nigeria (Orimono and al., 2007). It was explained that in the genus Macrobrachium, fruitfulness is associated extremely with the female age, and that it can increase while the female becomes ripe (Graziani and Al, 1993) and the size of eggs. The high average value of RGS (11.44) obtained to the PSS could be explained by the fact that for this period the ovaries of the individuals females reached a state of more thorough advance compared to the female collected during the GSS 2017 having a smaller index RGS (4.44). Kingdom and Erondu (2013) underline for this purpose that when index RGS lies between 10.55 and 15.57, the fresh water shrimps enter an intense phase of activity of reproduction. This is corroboration by the presence of the 
ovigerous females with the PSS, corresponding to the period of laying which takes place from July to December (Villé, 1972). It should be noted that the presence of the ovigerous females during the GSS 2017 which corresponds to the period of low water level could be explained by a new period of reproduction thus knowing that the reproduction of the genus Macrobrachium is not continuous throughout the year. In our basins slope the Macrobrachium dux reproduces twice a year since production is early and the eggs are rather broad by consequence the larval development is shortened. In this connection Gangbe and al., 2016 stress that reduced fruitfulness is compensated by early fecundation.

\section{CONCLUSION}

In relation to our work, the diversity and the fertility of shrimps of the genus Macrobrachium in the catchment area of Nyong, we conclude that our various rivers water are of good ecological quality which are slightly acid, fairly oxygenated, slightly mineral-bearing, slightly turbide but with a rather significant color. This rivers have a very significant diversity comprising 14 species of genus Macrobrachium which are, Macrobrachium macrobrachion, Macrobrachium rude, Macrobrachium niloticus, Macrobrachium dux, Macrobrachium idea, Macrobrachium sp1, Macrobrachium sp2, Macrobrachium sp3, Macrobrachium sp4, Macrobrachium sp4, Macrobrachium sp5, Macrobrachium sp6, Macrobrachium sp7 Macrobrachium sp8 and Macrobrachium sp9. Macrobrachium macrobrachion is dominate in the river Lepmassoun but Macrobrachium sp8 dominates in river Ondoamedza. We note as a whole an equal distribution of the species in the river Lepmassoun. They are diversified enough according to the index of diversity of Shannon. The équi-partition of the species in the river Ondoa medza is higher than river Lepmassoun. Macrobrachium macrobrachion significantly and positively correlated with Macrobrachium sp7. However this species negatively correlated with the the color. The species Macrobrachium sp5 positively correlated with the percntage of saturation out of $\mathrm{O}_{2}$. As regards Macrobrachium sp7, it has significantly and positively correlated with MES and alkalinity and finally Macrobrachium sp8 positively correlated with magnesic hardness.

The species Macrobrachium dux, had 3females ovigerous whose settlement is dominated by the females. The river Lepmassoun, the specie Macrobrachium dux enters in intense phase of activity of reproduction during the small dry season but another period of reproduction was observed during the great dry season. In our basins slope the Macrobrachium dux reproduces twice a year since production is early and the eggs are rather broad by consequence the larval development is shortened. The species Macrobrachium macrobrachion is a ubiquist in our two rivers, it is it more in the river Lepmassoun compared to the other species and average in the river Ondoamedza. For a better knowledge of the reproduction of Macrobrachuim in the forest belt in Cameroon it would be interesting to traverse other aquatic environments.

\section{REFERENCES}

[1] AE, A. d. 1. E. (1999). Système d'évaluation de la qualité de l'eau des cours d'eau: grilles de seuils par usage et fonction. version 1: 23.

[2] Agadjihouede, H. (2006). Diversité et exploitation des crevettes d'eau douce dans la lagune de GrandPopo (Bas-Mono). Département d'Aménagement et de Gestion de l'Environnement (DAGE). Bénin, Université d'Abomey-Calavi: 67.

[3] Ajeagah, A. G., et al. (2017). " Facteurs environnementaux et répartition spatiale des crustacés dans un cours d'eau peuanthropisé à makak (région du centre cameroun)." Physio-Géo Géographie Physique et Environnement XI: 181195.

[4] Ajeagah, G., et al. (2018). "Biomorphologie des crustacés d'un cours d'eau peu anthropisé en forêt équatoriale au Cameroun." Revue des sciences de l'eau 31(1): 29-40.

[5] Allan, J. D. and A. S. Flecker (1993). "Biodiversity conservation in running waters: identifying the major factors that threaten destruction of riverine species and ecosystems." Bioscience 43: 32-43.

[6] BIRAM à NGON, E. B., et al. "Ecological factors and Dictyoptera (Blaberidae) association -benthic macroinvertebrates, in some forest streams in the Centre region of Cameroon." International Journal of Advanced Research in Biological Sciences 5(7): $1-12$.

[7] Day, J. A., et al. (2001). Guides to the Freshwater Invertebrates of Southern Africa Bathynellacea,Amphipoda,Isopoda,Spelaeogriphace a,Tanaidacea,Decapoda. South Africa, Water Research Commission (WRC). 4: 151.

[8] De Grave, S. and C. H. J. M. Fransen (2011). "Carideorum Catalogus: The recent species of the Dendrobranchiate, Stenopodidean, Procarididean and Caridean shrimps (Crustacea: Decapoda)." Zoologische Mededelingen 85: 195-588.

[9] Djiriéoulou Kémomadjèhi, C., et al. ( 2017.). "Peuplement de la faune de crevettes de la Forêt des Marais Tanoé-Ehy (Sud-Est de la Côte d'Ivoire)." Journal of Applied Biosciences 112: 11100-11110.

[10] Doume doume, C. N., et al. (2013). " Effets des facteurs endogènes et exogènes sur la croissance de la crevette géante d'eau douce Macrobranchium 
rosenbergii de Man, 1879 (Decapoda : Palaemonidae) le long du fleuve Wouri au Cameroun." Interntional. Journal of Biologie and Chemestry Sciences (Int. J. Biol. Chem. Sci. ) 7(2): 584-597.

[11]FAO (2010, 2018). "Méthodes simples pour l'aquaculture. ." Retrieved 2018, from http://apps.fao.org/page/collections?subset=nutrition

[12] Foto Menbohan, S., et al. (2012). "Impact of dam construction on the diversity of benthic macroinvertebrates community in a periurban stream in Cameroon." International Journal of Biosciences 2(11): 137-145.

[13] Foto Menbohan, S., et al. (2017). "Santé écologique de quelques cours d'eau du bassin hydrographique de la Mabounié au Gabon : Essai de typologie par les variables physicochimiques et hydromorphométriques." European Journal of scientific Research 1(148): 93-105.

[14] Goore Bi, G. (1998). Contribution à l'étude des crevettes d'eau douce de la Côte d'Ivoire : systématique, biologie et analyse socio-économique de la pêche de Macrobrachium vollenhovenii (Herklots, 1857) et Macrobrachium mabrachion (Herklots, 1851) (Crustacea : Decapoda, Palaemonidae) du bassin de la Bia. Côte d'Ivoire, Université de Cocody.: 143.

[15] Griessinger, J. M., et al. (1991). "Elevage de la Crevette Tropicale d'Eau Douce." Institut Français de Recherche pour l'Exploitation de Mer: 372.

[16] IBGE, I. B. p. 1. G. d. 1. E. (2005). L'eau à Bruxelles. Institut Bruxellois pour la Gestion de l'Environnement / Observatoire des Données de l'Environnement: 16.

[17] Konan, K. M. (2009). Diversité morphologique et génétique des crevettes des genres Atya Leach, 1816 et Macrobrachium Bate, 1868 de Côte d'Ivoire. Sciences et Gestion de l'Environnement. Côte d'Ivoire, Université Nangui Abrogoua,: 170.

[18] MEDD and A. d. 1. E. AE (2003). Système d'évaluation de la qualité de l'eau des cours d'eau (SEQ-Eau): 40.

[19] Monod, T. (1966). Crevettes et crabes de la côte Occidentale d'Afrique, Instituts Fondamentales Noire. master: 77.

[20] N'zi, k. G., et al. (2008). "Influence des facteurs environnementaux sur la répartition spatiale des crevettes dans un petit bassin ouest africain - rivière Boubo - Côte d'Ivoire." Tropicultura 26(1): 17-23.

[21] New, B. and S. Singholka (1985). "Freshware prawn farming : a manual for the culture of Macrobrachium rosenbergii." FAO Fisheries Technical Paper Revue 1(225): 118 .
[22]NQS, N. d. Q. E. d. S. (2007). Grille de qualitéMaroc: 2.

[23] Olivry, J. C. (1986). Fleuve et rivières du Cameroun. Monographie Hydrologie. $\quad$ France, MESRE/ORSTOM: 781.

[24] Powell, C. B. (1980). "The genus Macrobrachium in West Africa; I: Macrobrachium thysi,a new largeegged species from the Cote d'Ivoire (Crustacea Decapoda Palaemonidae)." Rev. Zool. Afr. 94: 317326.

[25] Sampaio, C. M. S., et al. (2007). "Reproductive cycle of Macrobrachium amazonicum females (Crustacea, Palaemonidae)." Brazilian Journal of Biology 67: 551-559.

[26] SEQ-EAU, S. d. é. d. 1. q. d. 1. e. d. c. d. e., et al. (2013). Grilles d'évaluation SEQ-EAU (VERSION 2). 40 .

[27] Shannon, C. E. and W. Weaver (1948). he mathematical theory of communication. $\underline{T}$ University Illinois press,. Etat-Unis, Urbana: 117.

[28] Tchakonte , S., et al. (2014). " Impact of anthropogenic activities on water quality and freshwater shrimps diversity and distribution in five rivers in Douala, Cameroon." Journal of Biodiversity Environment and Sciences ( J. Biodiversity Environ. Sci.) 4(2): 183-194.

[29] Villeneuve, V., et al. (2006). "Dynamique et modélisation de l'oxygène dissousen rivière." $\underline{\text { Rev }}$. Sci. Eau, géol.: 259-274. 